\title{
Ikääntyminen ja elämän tarkoituksellisuus
}

\author{
Helena Honkanen Vartiainen
}

\section{Taustaa}

Väestön ikääntyminen on yhteiskunnallinen ilmiö, jonka vaikutuksia voi verrata ilmastonmuutoksen kaltaiseen megatrendiin (Sitra 2020). Ikääntymisen eri ulottuvuudet kietoutuvat yksilön kokemuksiin, terveyteen ja toimintakykyyn. Vanhuudessa vahvistuu usein tarve etsiä syvää merkitystä omalle elämälleen. Suvi Fried ja Ilka Haarni ovat keränneet Elämäntaidot esiin -kampanjan aineiston vastauksista elämäntaitoja, jotka tukevat ikääntyneiden hyvinvointia. Elämäntaidot perustuvat elämänkokemuksen kartuttamaan viisauteen ja osaamiseen. Ne ovat selviytymisen keinoja ja elämänymmärrystä, käytännöllisiä taitoja, itsestä huolehtimisen taitoja, vuorovaikutustaitoja, hengellisiä elämäntaitoja sekä mielen taitoja (Fried \& Haarni 2017). Elämän tarkoituksellisuuden näkökulman sisällyttäminen keskusteluun rakentaa kokonaisvaltaista käsitystä hyvästä ikääntymisestä vahvistaen myönteistä vanhuuskuvaa.

Useat ikääntymisen teoriat ovat rakentuneet psykologi Erik H. Eriksonin psykososiaalisen elämänkaariteorian pohjalta. Kehitystä ohjaa yksilön ja yhteiskunnan jatkuva keskinäinen vuorovaikutus. Eriksonin kehitysteorian viimeinen vaihe on vanhuus, jonka kehitystehtävä on minän eheys. Eriksonin teoriassa vanhuuden kehitysvaiheen onnistuneeseen ratkaisemiseen sisältyy ajatus elämän tarkoituksen sisäistämisestä. Mikäli vanhuuden kehitystehtävä epäonnistuu, minän eheyden vastakohdiksi jäävät epätoivo ja katkeruus. Vanhuuden mahdollistama positiivinen voima on viisaus. Viisaus on Eriksonin mukaan avoimuutta ja kiinnostusta elämää kohtaan - myös kiinnostusta kuoleman edessä ja lähestyessä. Jotta viisauden voi saavuttaa, tarvitaan kokemus eheydestä fyysisellä, psyykkisellä ja sosiaalisella tasolla (Dunderfelt 1990). Elämänvaiheena vanhuuden ajatellaan olevan aikaa, jolloin monet päätyvät pohtimaan hengellisiä tai filosofisia kysymyksiä (Takkinen 2003).

Itävaltalaisen lääkärin Viktor Franklin tuotannon läpi kulkee elämän tarkoituksellisuuden teema. Frankl ajattelee, että ihmiselle luonteenomaista on etsiä olemassaololleen tarkoitus. Omakohtainen keskitysleirikokemus sai hänet muodostamaan elämänfilosofian, joka tunnetaan eksistenssianalyysinä eli logoterapiana, jonka tavoite on ohjata ihminen elämäntarkoituksensa löytämiseen. Tarkoituksellisuutta voi Franklin mukaan kokea kaikissa olosuhteissa. Vanhuus asettaa yksilölle vaatimuksia, joihin henkilön on vastattava. Siitä syystä esimerkiksi ikääntyneen toimintakyvyn heikentyminen, sairaudet tai elämänmuutoksista ja menetyksistä syntyvä haavoittuvuus eivät poissulje tai automaattisesti vähennä elämän tarkoituksellisuuden tunnetta (Frankl 1986). Juuri hauraus ja haavoittuvuus voivat muodostua ikääntyneen voimavaraksi. Haavoittuvuus pitää sisällään avoimuuden ja herkkyyden, jonka varassa ikääntynyt kohtaa vanhenemisen mukanaan tuomat haasteet. Hauraus ja haavoittuvuus mahdollistavat oman vanhenemisen hyväksymisen ja vanhuuteen liitetyn viisauden kasvamisen (Sarvimäki \& Stenbock-Hult 2010). 
Kokemus elämän tarkoituksellisuudesta korreloi elämän tyytyväisyyden, hyvän itsetunnon, hallinnan tunteen ja toimintakyvyn kanssa (Takkinen 2003).

\section{Ikääntyminen ja tarkoituksellisuus - kolme näkökulmaa}

\section{Hyvä ikääntyminen - Frits de Lange}

Etiikan professori Frits de Lange (2010) esittää, että nykyeetoksen mukaiseen menestykselliseen vanhenemiseen sisältyy hyvän terveyden ja jatkuvan aktiivisuuden säilymisen ihanne. Nykyajan kilpailu- ja järkikeskeisessä maailmankuvassa elämän tarkoitus unohtuu, minkä vuoksi tarvitsemme uuden tavan katsoa vanhenemista. De Lange on valinnut ikääntymiseen eettisen lähestymistavan seuraavien viiden ulottuvuuden kautta:

- Ihmisen luonnollisten, fyysisten ja psyykkisten tarpeiden tulee olla täytetty.

- Yksilö saa olla arvostettu osa yhteisöään.

- Hänellä on oikeus elää vakaumuksensa mukaan.

- Hän osaa antaa merkityksen elämälleen.

- Tasapainoilun taito näiden ulottuvuuksien välillä.

Tasapaino ulottuvuuksien välillä on tärkeä.̈.Jos ikääntynyt saa olla rakastettu ja arvostettu yhteisössään, se korvaa esimerkiksi heikentynyttä fyysistä kuntoa. Yhdessä ulottuvuudessa löytyvä vahvuus korvaa menetettyä vahvuutta toisessa. Eri maanosien, kulttuurien ja uskontojen suurissa kertomuksissa hyvä ja paha esiintyvät metaforina ja myytteinä. Kasvamme aina jonkin suuremman kertomuksen kanssa, riippuen siitä mihin olemme syntyneet. Kertomukset rakentavat kuvaamme maailmasta ja merkitysympäristöstä; ne ovat tapa liittyä toisiin ihmisiin ja maailmaan. Jaettu tarina ylittää yksilön henkilökohtaisen minän. De Langen mukaan merkitykselliseen ja hyvään elämään kuuluu itsemme löytäminen tuosta kokonaisuudesta. Se voi olla uskonnollisesti tulkittu maailmankuva, historiallinen tai filosofinen suuntaus ja näkemys, sukupolven jaetut tarinat ja kokemukset tai oma perheyhteisö. Ilman jonkinlaista kehystä, johon henkilö kuuluu, elämä voi tuntua merkityksettömältä.

Ikääntymisessä on kaksi puolta. Haurastuminen antaa uuden olomuodon, mutta samanaikaisesti kasvaa kyky syvempään olemiseen. De Lange kuvaa ikääntymistä samanaikaiseksi tappioksi ja voitoksi, etenemiseksi ja taantumiseksi. Juuri myytit, uskonto ja hengellisyys ovat keinoja, joilla tätä ambivalenssia, kaksijakoisuutta, voi hallita. Ikääntyneen elämä ei täyty enää arkisista toimista ja velvollisuuksista. Liittoutuminen mysteerin, jonkin itseään suuremman kanssa, voi muodostaa pohjan omalle olemassaololle. Tällainen henkinen ulottuvuus on länsimaissa viety pitkälti yksityisen elämän piiriin, pois yhdessä jaetusta, arkisesta elämästä. Sen näkyminen tarkoittaisi kuoleman ja vanhuuden olemassaolon tunnustamista.

\section{Perimmäinen tarkoitus \\ - Elizabeth MacKinlay}

Tutkija, pappi ja sairaanhoitaja Elizabeth MacKinlay sijoittaa elämän perimmäisen tarkoituksen välittämisen ja siihen vastaamisen hengellisyyden käsitteen alle. Hän näkee yksilön keskeisimmäksi tehtäväksi elämän perimmäisen tarkoituksen löytämisen. Vaikka yksilön psykologinen toiminta saattaa ikääntyessä heikentyä, hän kykenee yhä kehittämään hengellistä ulottuvuuttaan. Vaikka MacKinlay on tutkimuksissaan kuvannut yksilön elämän tarkoituksen olevan osa hengellisyyttä, ei spiritualiteetti hänen mukaansa rajoitu vain uskonnollisuuteen. Hengellisyyteen kuuluvat MacKinlayn mukaan ympäristö (luonto, meri, vuoret, puutarha), uskonto (jumalanpalvelus, rukoileminen, meditaatio), taiteet, (musiikki, taide, tanssi) ja suhteet (läheisyys Jumalan ja ihmisten kanssa) (MacKinlay 2006). Viktor Frankl (1981) on kirjoittanut kirjassaan keskitysleiriolosuhteista, joissa kuoleman jatkuvassa 
läsnäolossa vankien sisäinen elämä voimistui niin, että luonnon ja taiteen kauneus koettiin voimakkaammin kuin koskaan aiemmin. MacKinlay löysi ikääntyneille tekemissään syvähaastatteluissa seuraavat hengellisyyteen ja ikääntymiseen liittyvät teemat, jotka ovat vuorovaikutuksessa keskenään ja rakentuvat kaikki elämän perimmäisen tarkoituksen ympärille:

- elämän perimmäinen tarkoitus ja siihen vastaaminen

- toivo ja pelko

- ihmissuhteet ja eristäytyminen

- viisaus ja lopullisen tarkoituksen löytäminen

- itseriittoisuus ja haavoittuvuus

Elämän perimmäinen tarkoitus sisältää suhteen Jumalaan sekä käsitykset muista ihmisistä ja uskonnon olemassaolosta. Tapa, jolla ikääntynyt reagoi perimmäiseen tarkoitukseen, riippuu monista tekijöistä: perhetaustasta, lapsuudesta, koulutuksesta ja elämän varrella kertyneistä kokemuksista. Siihen vaikuttavat kriisit, joita yksilö on kokenut elämässään, sekä selviytyminen niissä. Itseriittoisuus ja haavoittuvuus ovat fyysisen ikääntymisen tuomaa kyvyttömyyttä ja sen vaikutuksia. Haavoittuvuus voidaan yhdistää transsendenssin, tuonpuoleisuuden, löytämiseen, joka auttaa ylittämään tätä haavoittuvuutta. Toivo on yhteydessä yksilön eheyden kokemukseen. Toivo toteutuessaan tukee yksilön hengellistä eheyttä, tyytyväisyyden, rauhan, ilon ja merkityksellisyyden tunteita, tai toisaalta merkityksettömyyden tunteita.

Elämän lopullinen tarkoitus ja siihen vastaaminen liittyvät yksilön käsityksiin elämän loppumisesta eli kuolemasta. Viisauden ja transsendenssin, tuonpuoleisen, ymmärtäminen antaa ikääntyvän elämälle uusia merkityksiä. MacKinlayn tutkimuksessa viisaus ymmärretään suurempana toleranssina sietää todellisuuden ristiriitaisuutta, epävarmuutta sekä elämän tarkoituksen etsimistä. Siirtyminen ulkoisesta maailmasta omaan sisäiseen maailmaan on osa lopullisen tarkoituksen löytämistä (MacKinlay 2001). MacKinlay (2006) ko- rostaa yksilön oman elämäntarinan kertomisen merkitystä tarkoituksen löytämisessä ja eheyden saavuttamisessa.

\section{Gerotranssendenssiteoria - Lars Tornstam}

Sosiologian professori Lars Tornstam luomaa, gerotranssendenssiteoriaksi kutsuttua teoriaa pidetään positiivisen ikääntymisen teoriana, joka kuvaa vanhuuden psyykkistä ja sosiaalista kehitystä. Sen mukaan ikääntyneen viisaus ei rakennu vain eletylle elämälle ja sille annetuille merkityksille, vaan yksilölle aukeaa hänen ikääntyessään kokonaan uusi elämänperspektiivi. Arvot muuttuvat, samoin suhtautuminen omaan itseen ja toisiin ihmisiin. Tornstam luettelee gerotranssendenssikehityksen tuomia perspektiivimuutoksia. Niitä ovat kasvava tunne kuulumisesta maailmankaikkeuteen, ajan, avaruuden ja tilan uudelleenmäärittely sekä elämän ja kuoleman välistä suhdetta koskevat kysymykset. Ikääntynyt kehittyy kohti kosmista minuutta, jossa sinun ja minun rajat vähenevät. Kuolemanpelon väistyminen kuuluu kosmisen ulottuvuuden mahdollisuuksiin. Ikääntynyt voi hyväksyä jonkinlaisen mysteerin olemassaolon. Kaikki tämä liittyy elämän tarkoituksen kysymiseen. Tornstamin gerotranssendenssiteorian mukaan seuraavat kolme ulottuvuutta vievät yksilöä kohti eheyttä ja viisautta:

- kosminen ulottuvuus

- minuuden kehityksen ulottuvuus

- sosiaalisten suhteiden ulottuvuus

Ihmisen ikääntyessä raja menneen ja tämän hetken välillä heikentyy. Lapsuuden ja lapsuusmuistojen merkitys kasvaa. Yhteenkuuluvuuden tunne aiempien ja tulevien sukupolvien kanssa lisääntyy. Yksilö hyväksyy eletyn elämänsä. Hänen ymmärryksensä minuuden erilaisista puolista kasvaa, mikä johtaa itsekeskeisyyden vähentymiseen. Tämä tarkoittaa yksilön omaa hyvää tavoittelevan egoismin korvautumista muita huomioivalla altruismilla. Ikääntyneen aktiivisuus on fyysisen aktiivisuuden sijaan psyykkistä aktiivisuutta, kuten oman menneen 
elämän pohdiskelua. Yksilön tulee voida vaikuttaa ikääntyneenäkin elämäänsä ja määrätä itse, miten jäljellä olevan aikansa käyttää. Myös ikääntyvän sosiaaliset suhteet muuttuvat minän muuttuessa. Yksilö tulee valikoivammaksi ihmissuhteissaan ja haluaa viettää aikaa myös yksin. Hän jättää elämässään olleita rooleja taakseen ja voi olla vapautuneemmin oma itsensä. Tavallinen hyvä arki riittää, mitä Tornstam kuvaa moderniksi asketismiksi. Ikääntynyt ei arvosta aineellisia asioita niin korkealle kuin aiemmin elämässään. Suvaitsevaisuus ja muu avarakatseisuus lisääntyvät. Teorian esittämiä muutoksia ei voida pitää kaikkia ikääntyviä koskevana kehitystapahtumana, vaan se on vain yksi mahdollinen kehityssuunta kaikkien muiden joukossa. Tutkimusten mukaan prosessi alkaakin jo nuorena aikuisena ja jatkuu korkeaan ikään saakka. Prosessi voi sekä kiihtyä että hidastua riippuen yhteiskunnan ja yksilön elämänvaiheista ja tapahtumista (Tornstam 2005).

\section{Relaatiot eheyden rakentajana}

Kaikissa edellä esitellyissä teorioissa otetaan kantaa relaatioihin, suhteessa ja suhteissa olemisiin. De Lange painottaa ihmisen roolia osana yhteisöään. MacKinlay nostaa ihmissuhteet osaksi elämän tarkoituksen löytämistä. Myös Tornstamin gerotranssendenssiteorian yksi ulottuvuuksista liittyy sosiaalisiin suhteisiin.

Erikson on nostanut kehityspsykologisessa mallissaan yhdeksi tärkeimmäksi ihmisen olemassaoloa täydentäväksi puoleksi "yhteisölliset tapahtumat, ihmisten vastavuoroisen riippuvuuden toisistaan kulttuurisessa kokonaisuudessa” (Dunderfelt 1990, 243). Kuuluminen on osallisuutta myös johonkin suurempaan kollektiiviin. De Langen teoriassa yksilön etsiessä tätä yhteisöä maailma tarjoaa kiinnittymiseen tarinan, myytin tai kertomuksen, jonka avulla kuulumme yksilöinä yhteiskunnassa jaettuun kulttuuriin ja olemme osa jaettua kokemusmaailmaa. Kuuluminen voi liittyä ystävyyteen, perhesuhteisiin tai uskonnolliseen yhteisöön.
Yksilö kokee tarvetta olla osa suurempaa tarinaa, ja yhteisöt muodostuvat yksilöiden voimasta. Länsimaiset yhteiskunnat rakentuvat yksilökulttuurille, joka puolustaa yksilön autonomiaa ja oikeuksia, mikä asettuu toisinaan ristiriitaan yhteisöllisyyttä korostavan näkemyksen kanssa (de Lange 2010). MacKinlay korostaa sitä, että useilla ikääntyneillä ihmissuhteet antavat elämälle merkityksen. Suhde Jumalaan ja toisiin ihmisiin muodostavat yksilön elämäntarkoituksen, joita tarvitsemme valmistautuessamme "kotimatkaan" (MacKinlay 2001). Filosofi Rosi Braidottin mielestä ihmisen minuus on tottumus tai tapa, jota ihminen eri elämäntilanteissa kokemuksensa kautta uusintaa."Vaikka meillä on kyky identifioitua, kyky sanoa "minä", joka ei suinkaan ole kyky, jonka me itse jollain tavalla aikaansaisimme, vaan lahja, jonka saamme maailmalta. Se on lahja heiltä, jotka ilmein, elein, merkein ja sanoin vastaavat siihen parkaisuun, jonka me vastasyntyneinä olioina kehostamme päästämme. Me emme ole täällä yksin, vaan osallisina kielessä, jossa kaikki on yhteistä ja liittyy kaikkeen." (Ojansuu 2011, 115.)

Suhteessa olemisen peilikuvana ikääntymisen teorioista nousee esiin myös erillisyys, vapaaehtoinen erkaantuminen maailmasta. Tällaisen irtaantumisteorian mukaan tarve vetäytyä on luonnollinen, biologisperusteinen osa ihmisen elämänkaarta. Se auttaa ikääntyvää kohti hyvää vanhenemista ja valmistaa kuolemaan. Yksilö ja yhteiskunta irtautuvat vähitellen toisistaan. Tällainen ajattelumalli on vaikuttanut voimakkaasti vanhuuspoliittisten päätösten taustalla, vaikka se ei olekaan saanut varauksetonta kannatusta (Jyrkämä 2003). Gerotranssendenssiteoria kuvaa tätä kehitystä siten, että arvojen muuttuessa yksilö luo uuden suhteen sosiaaliseen verkostoonsa. Siihen kuuluu keskittyminen harvempiin ihmissuhteisiin ja viihtyminen itsekseen (Tornstam 2005). De Lange sanoo tämän olevan individualistisen mallin mukaisesti toimiva järjestys, jossa ketään ei velvoiteta jakamaan arvojaan tai elämäntapojaan toisen kansalaisen kanssa. Sen riskinä on kui- 
tenkin, että ihmiset syrjäytetään sosiaalisesta ja lääketieteellisestä avusta. Syrjäyttäminen ei johdu vain siitä, että he ovat vanhoja, vaan siitä, että heidät nähdään autonomisina, yksin pärjäävinä toimijoina, vaikkei näin olisikaan (de Lange 2010).

\section{Haavoittuvuus ehtona ymmärrykselle}

MacKinlay nimeää teoriassaan itseriittoisuuden ja haavoittuvuuden toistensa vastinpareiksi. De Lange kuvaa haavoittuvuutta luonnollisten tarpeiden kautta: ikääntyneen biologisiin, sosiaalisiin ja psykologisiin tarpeisiin (ruoka, intimiteetti, turvallisuus, rakkaus, kunnioitus) tulisi pyrkiä vastaamaan. Toisinpäin käännettyinä ne ovat yksilön haavoittuvuustekijöitä. Tornstamin gerotranssendenssiteoriassa haavoittuvuutta ei mainita itsenäisenä ulottuvuutena, mutta se liittyy yksilön ja ympäristön keskinäiseen suhteeseen.

Haavoittuvuus ei tarkoita vain ruumiillista heikkoutta. Haavoitetuksi voi tulla sosiaalisten suhteiden tasolla, esimerkiksi elämänkumppanien tai ystävien menetysten kautta. Läheiset ihmiset saattavat korvautua ammattiauttajilla (Sarvimäki ym. 2010). Ikääntymiseen liittyy usein yksilön toimintakyvyn heikkenemistä tai sairastumista. Erilaisista tekijöistä koostuva eksistentiaalinen haavoittuvuus ei liity kuitenkaan vain ihmisen omaan fyysiseen haurauteen tai riippuvuuteen toisista ihmisistä. Ongelmat ovat paikannettavissa yhteiskunnan rakenteisiin, mistä vaikutus leviää muihin elämän osa-alueisiin. Näitä rakenteissa tarkasteltavia asioita ovat terveydenhoitoon ja toimintakykyyn liittyvät asiat, kuten laitoshoitoon pääseminen (Laceulle 2018a). De Lange korostaa, että ikä on merkityksellinen asia sekä henkilökohtaisesti että poliittisesti,ja se tulee huomioida perhepolitiikassa, lainsäädännössä ja eläkeläisten sosiaaliturvassa. De Lange (2010) kritisoi yhteiskunnassa vallitsevaa vanhuuden kieltämistä, joka huonontaa ikääntyneiden mahdollisuutta elää hyvää vanhuutta.

Hollantilaisen tutkijan Hanne Laceullen mukaan tuotamme ikääntymisestä haitallisia stereotypioita ja kertomuksia. Yhteisömme tarinat eivät huomioi ikääntymiseen sisältyviä mahdollisuuksia. Jos katsoisimme ikääntymistä hyväksyen siihen sisältyvän haavoittuvuuden, rakentaisimme ehjempää kulttuuria. Laceulle korostaa ikääntyneen elämän kehitystehtävien merkitystä. Ihminen havaitsee nämä kehitystehtävät intuitiivisesti ja pyrkii vastaamaan niihin. Tällainen näkökulma tarjoaa vastavoiman kulttuuritarinoille, joissa ikääntyminen nähdään vain luopumisena. Laceulle korostaa, että yksilön koko elämällä, myös vanhuudella, on tehtävä: tarkoitus on tulla yhä enemmän "häneksi, joka sinä olet" (Laceulle 2018b). Gerotranssendenssissä ikääntymisen aiheuttamaa haavoittuvuutta hallitaan psyykkisellä aktiivisuudella, jolloin yksilö pohtii elämänkaarensa tapahtumia ja löytää niistä merkityksen elämälleen. MacKinlay ajattelee Eriksonin tavoin elämänkokemusten jalostuvan viisaudeksi. Vanhuudessa nähty yksilön kehitysmahdollisuus auttaa yhteiskuntaa tukemaan eksistentiaalisen haavoittuvuuden vaiheeseen tulleita ihmisiä ja vahvistaa samalla heitä elämäntarkoituksen löytämisessä.

Haavoittuvuus voi tarjota MacKinlayn (2001) mukaan polun kurkotella rajan yli tuonpuoleiseen. Kuolevaisuus tarjoaa sisäiset rajat ihmisen olemassaololle ja antaa mahdollisuuden olla suhteessa äärellisyyden ja äärettömyyden sekä ajallisuuden ja iankaikkisuuden välillä (Schott 2010). Useat filosofit korostavat, että kuoleman lähestymisen tiedostaminen tarjoaa uutta ymmärrystä elämästä itsestään. Elämän rajallisuus ja sen esiin nostattamat kysymykset liittyvät ihmisen elämän ainulaatuisuuteen ja ainutkertaisuuteen.

\section{Mysteeri tarjoaa rajanylityspaikan}

Edellä tarkastellut teoriat liittävät elämän tarkoituksellisuuden osaksi hengellisyyttä ja mystiikkaa, joka tukee yksilön kokemusta eheydestä. Teoriat pyrkivät sanoittamaan käsittein vaikeasti kuvattavaa tuntematonta. Tornstam 
nostaa gerotranssendenssiteoriassaan kosmisen ulottuvuuden yhdeksi kolmesta pääteemastaan. De Lange korostaa yksilön kykyä löytää merkitys ja oikeutta elää vakaumuksensa mukaisesti. MacKinlayllä käsikkäin kulkevat viisaus ja lopullisen tarkoituksen löytyminen. Mystikko Johann Eckhart (1260-1327) on kirjoittanut "pyhyyden olevan lahja, jonka vanhuuden ymmärrys antaa. Se on lahja, jonka kautta me osallistumme rajallisuutemme ja haurautemme kohtaamiseen, lahja, jonka me saamme tämän kohtaamisen seurauksena."(Ojansuu 2011,73.) Viktor Frankl määrittelee ihmisen transsendenttiseksi olennoksi, joka ulottuu kohti äärettömyyttä. Kuoleman läheisyyden ymmärtäminen saa meidät tunnistamaan transsendentin olemassaolon. Mysteeri nimetään pyhyydeksi, hengellisyydeksi, spiritualiteetiksi tai transsendentiksi. Teologian sanakirjassa spiritualiteetti määritellään hengellisyydeksi, hengelliseksi elämäksi tai hengelliseksi habitukseksi. Henkisyys on todellista läsnäoloa, jolloin ihminen on läsnä itselleen ja toisille, luonnolle, kosmokselle ja jumalalliselle, pyhälle. Hengellisyyttä ei voida pelkistää mihinkään paikoilleen. Se ei rajoitu psykologiaan, uskontoon tai ihmissuhdetaitoihin (Streeter 2012).

Gerotranssedenssiteorian mukaan kosminen ulottuvuus on ikääntyvälle aukeava mahdollisuus. Tornstam käyttää vertauskuvana zenbuddhalaisuutta, jossa materiaalisessa maailmassa eläen kurkotellaan rajan yli"toiselle puolelle". Gerotrassendenssiin kuuluu liittoutuminen mysteerin kanssa ja sen antama lopullisen elämäntarkoituksen löytyminen. Ikääntynyt kokee tarvetta pohtia kuoleman jälkeistä elämää, mikä voi auttaa kuolemanpelon väistymiseen. Tornstamin mukaan opettelemme lapsuudessa rajoja sinun ja minun tai todellisuuden ja fantasian välillä, ja vanhuudessa palaamme uudelleen tähän lapsuuden maailmaan (Tornstam 2005).

Frits de Lange pitää spirituaalisuuden tukemista osana yksilön hyvää ikääntymistä ja näkee sen auttavan elämän tarkoituksen löytämisessä. Hän ajattelee, ettei henkisyyttä tule eristää vain yksityisen elämän piiriin, kuten liberaaleissa yhteiskunnissa tapahtuu. Yhteys uskontoon on luonnollinen väylä, mutta de Lange korostaa, ettei elämän tarkoituksen kysyminen saa olla vain uskontojen monopoli. Pitää tunnustaa myös taiteen ja kirjallisuuden merkitys, kuten myyttinen kertomus Odysseuksesta tai Beethovenin sinfoniat. Nämä ovat yhtä lailla osa yksilön "pyhän kaipuuta" ja siihen vastaamista. Yhteisöjen moniarvoistuminen ja institutionaalisen uskonnollisuuden heikentyminen on tehnyt hengellisen ulottuvuuden nimeämisen koko ajan vaikeammaksi. Inhimillinen olemassaolo on aina ylittänyt rajansa etsien tarkoitusta (de Lange 2010).

Elizabeth MacKinlayn mielestä eheyden saavuttaminen on viisauden saavuttamista. Hengellisestä näkökulmasta katsottuna viisaus on syvää inhimillisyyttä, johon sisältyy elämän perimmäisen tarkoituksen etsiminen. Hänen mukaansa ikääntyvä tullessaan tietoiseksi omasta kuolemastaan alkaa nähdä elämänsä lopullisen tarkoituksen (MacKinlay 2006). Hän mainitsee de Langen tavoin uskonnon, musiikin, taiteen ja ympäristön merkityksen perimmäisen tarkoituksen löytämisessä. Hänen ajatuksensa tulee lopulta lähelle Tornstamin gerotranssendenssiteorian kosmista ulottuvuutta. Kukan ihailu voi olla arkipäivän ilo, jonka muodostaman mikrokosmoksen kautta yksilö kokee olevansa osa suurempaa makrokosmosta (Tornstam 2005).

\section{Lopuksi}

Useimmiten elämänkaaren psykososiaalisen tulkinnan keskiössä on ajatus siitä, että ihminen kehittyy ulkoisten ja sisäisten tekijöiden vuorovaikutuksessa. Yhteiskunnallinen näkökulma korostaa ympäristön, yhteiskunnan, kulttuurin ja aikakauden vaikutusta ihmiselämään. Yksilön elämää voidaan parantaa kehittämällä yhteiskunnallisia ja kulttuurisia tekijöitä (Dunderfelt 1990). Psykososiaalinen näkemys ei juuri ota kantaa henkisyyteen uskonnollises- 
sa, filosofisessa tai mytologisessa mielessä. Tästä syystä ikääntymisen teoriat, jotka vastaavat elämän tarkoituksen kaltaisiin ikuisuuskysymyksiin, koskettavat inhimillisyyttä syvästi ja voivat hyödynnettyinä auttaa ikääntyviä ymmärtämään elämäänsä ja omaa paikkaansa maailmassa.

Frits de Langen etiikkaan painottuva teoria hyvästä ikääntymisestä, Elizabeth MacKinlayn elämän perimmäisen tarkoituksen teoria sekä Lars Tornstamin gerotranssendenssiteoria tuovat oman painotuksensa elämän tarkoituksellisuuden kysymykseen. Ikääntyneen elämän tarkoituksen erityislaatuisuus rakentuu kolmen merkittävän tekijän varaan. Toisiinsa yhteen kietoutuen nämä tekijät ovat relaatiot, haavoittuvuus ja mysteeri (Honkanen Vartiainen 2020). Kun ikääntyminen toimii siivilänä elämän tarkoituksen teorioille, läpi pääsevien kolmen

\section{Kirjallisuus}

De Lange F. (2010) Good ageing: a comprehensive approach. Teoksessa: Bouwer J, toim. Successful ageing, spirituality and meaning. Leuven: Peeters, 2010:171-189.

Dunderfelt T. (1990). Elämänkaaripsykologia. Helsinki: WSOY, 1990.

Frankl V. Ihmisyyden rajalla. Helsinki: Otava, 1981.

Frankl V. Ehjä ihmiskuva. Helsinki: Kirjayhtymä, 1986.

Fried S, Haarni I. Ikääntyvien elämäntaidoissa kiteytyy elämänkokemuksen moni-ilmeisyys. Gerontologia 2017;31(2):133-41.

Honkanen Vartiainen H. Ikääntyminen ja elämän tarkoituksellisuus. Kanditaatintutkielma. Helsingin yliopisto, pastoraaliteologia, 2020.

Jyrkämä J. Toimintakyvyn arviointimenetelmät. Teoksessa: Heikkinen E, Rantanen T, toim. Gerontologia. Helsinki: Duodecim, 2003:267-71.

Laceulle H. Ageing and self-realization: cultural narratives about later life. Bielefeld: Transcript Verlag, 2018a.

Laceulle H. Aging and the ethics of authenticity. Gerontologist 2018b;(58)5:970-8. https://doi.org/10.1093/geront/gnx037

MacKinlay E. The spiritual dimensions of ageing. London: Jessica Kingsley Publishers, 2001.

MacKinlay E. Spiritual growth and care in the fourth tekijän varaan kerääntyvät lopulta yksilön ja yhteiskunnan kaikki ulottuvuudet, asenteet ikääntymistä kohtaan, kulttuurin tuottamat kertomukset sekä yhteiskunnan rakenteet ja palvelut. Voimattomuuden tunne ikääntymistä kohtaan väistyy; ikääntymisestä paljastuu tutkijoiden tarjoaman linssin läpi mahdollisuuksia. Niiden tiedostamisen kautta ja vahvalla arvo-osaamisella voidaan tukea ikääntyneen kokonaisvaltaisen hoivan mahdollistumista ja yksilön eheyden saavuttamista.

\section{Teksti perustuu Helsingin yliopiston pastoraaliteo- logian oppiaineen kandidaatintutkielmaan.}

\section{Yhteydenotto: \\ Helena Honkanen Vartiainen, TK \\ Helsingin yliopisto \\ helena.honkanenv@gmail.com}

age of life. London: Jessica Kingsley Publishers, 2006.

Ojansuu J. Pyhyys. Helsinki: WSOY, 2011.

Sarvimäki A, Stenbock-Hult B. Vanhuus, haavoittuvuus ja hoidon eettisyys. Teoksessa: Sarvimäki A, Heimonen S, Mäki-Petäjä-Leinonen A, toim. Vanhuus ja haavoittuvuus. Helsinki: Edita, 2010:33-58.

Sarvimäki A, Stenbock-Hult B, Heimonen S. Ikääntyminen ja mielen haavoittuvuus: haavoittuvuus riskinä ja voimavarana. Gerontologia 2010;24(2):169-78.

Schott RM. All men are mortal. In: Schott RM, ed. Birth, death, and femininity: philosophies of embodiment. Indiana: Indiana University Press, 2010:3-8.

Sitra. Megatrendit 2020. Internet: https://www.sitra. fi/aiheet/megatrendit/\#megatrendit-2020 (viitattu 3.3.2020).

Streeter CM. Foundations of spirituality: the human and the holy: a systematic approach. Minnesota: Liturgical Press, 2012.

Takkinen S. Elämän tarkoituksellisuuden tunne. Teoksessa: Heikkinen E, Rantanen T, toim. Gerontologia. Helsinki: Duodecim, 2003:210-9.

Tornstam L. Åldrandets socialpsykologi. Stockholm: Norstedts akademiska förlag, 2005. 